\title{
"Çocuktan Al Haberi" Yarışma Programında Yetişkin Bakışının Ürettiği Çocuk Temsilleri ve Yetişkincilik
}

DOI: 10.26466/opus.601065

\author{
Erman Bostan* \\ * Uzman, Anadolu Üniversitesi, Sosyal Bilimler Enstitüsü, Eskişehir/Türkiye \\ E-Posta: erman.bostan@gmail.com \\ ORCID: $\underline{0000-0003-1356-7906}$
}

\begin{abstract}
Öz
Toplumsal algıda çok yaygın bir 'doğal' çocuk imgesi bulunmaktadır. Bu imge yetişkin ve çocuk arasında bir ayrım yaparak hiyerarşik bir güç ilişkisi tahsis eden yetişkin bakışına dayanmaktadır. Yetişkin bakışı çocuğu, onda görmeyi arzuladığ bir takım şablonlara uymaya zorlayarak keyif verici performanslara indirger. Yetişkincilik olarak tanımlanan bu güç ilişkisinde yetişkinler çocuğun zayıflı̆̆ını, güvenini, romantizmini ve idealleştirmelerini kötüye kullanarak çocukları denetler, kontrol eder ve yönlendirirler. "Çocuktan Al Haberi" yarışma programı da bu tür bir bakış açısını hem programın görsel yapısı hem de çocuklar üzerine kurulan söylemler üzerinden yeniden-üretir. Çocukları bağgrmsız bireyler, benzersiz kendilikler olarak görmek yerine, gelişimsel açıdan gösterdikleri sembolik dışavurumlar önceden hazırlanmış senaryolarla keyif verici performanslara dönüştürülür ve yeni bir tür hakimiyet tahsis edilir. Bu sebeple çalışmada eleştirel söylem analizi ve göstergebilimsel çözümleme, betimsel bir analizin parçası olacak biçimde sentezlenmiştir. Programda çocuklar tipik olarak sevimli ve bilmiş temsiller yoluyla, daha çok seyirlik canlular olarak sunulurlar. Çocuk imgeleri ile toplumda yaygin ideolojiler arasında gizli bir ilişsi vardır. Çocuklara karşı geliştirilen bakış açıları aynı zamanda yetişkin toplumun kendisine 'kim' olduğunu söyleme tarzların yansıtır.
\end{abstract}

Anahtar Kelimeler: Çocuk, Temsil, Yetişkincilik, Yetişkin Bakışı, Medya 


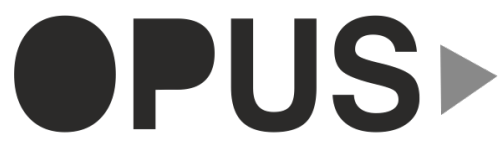

Uluslararası Toplum Araştırmaları Dergisi International Journal of Society Researches
E-ISSN : 2528-9535

YIl Year: 9

Cilt Volume: 14

Sayı Issue :20

Aralık December 2019

Makalenin Gelis Tarihi Received Date: 03/08/2019

Makalenin Kabul Tarihi Accepted Date: 08/12/2019

\title{
Representations of Children Produced by the Adult Gaze in the "Çocuktan Al Haberi" Quiz Show and Adultism
}

\begin{abstract}
We have a widespread image of 'natural' children, which is now very natural to us. This image is based on the adult gaze that allocates a hierarchical power relationship by making a distinction between adult and child. The adult gaze degrades the child to pleasant performances by forcing him to follow a set of templates he wishes to see. In this power relationship, which is defined as adultism, adults inspect, control and manipulate children by abusing their weakness, confidence, romance and idealization. "Çocuktan Al Haberi" quiz show reproduces this kind of point of view through both the visual structure and the discourses established on children. Instead of seeing children as independent individuals and unique, their developmental symbolic expressions are transformed into pleasurable performances with pre-prepared scenarios and a new kind of dominance is allocated. For this reason, critical discourse analysis and semiotic analysis were synthesized as part of a descriptive analysis. In the quiz show, children are mostly presented as living creatures through charming and smarty representations. There is a latent relationship between the images of children and dominant ideologies in society. The perspectives developed against children reflect the ways in which adult society tells themselves 'who' they are.
\end{abstract}

Keywords: Child, Representation, Adult Gaze, Adultism, Media 


\section{Giriş}

"Çocuk ve medya" ile ilişkili tartışmalar çoğunlukla I. Dünya Savaşı süreci ve sonrasında, iletişim çalışmalarına hakim olan propaganda sorunu etrafında gelişen "güçlü etkiler" geleneğinin bir uzantısı olarak şekillenmiştir. Çalışmalarda sıklıkla medyanın, özellikle de televizyonun "zararlı etkilerinden" bahsedilir: kötü alışkanlıkların ve olumsuz örnek olabilecek davranışların benimsenmesinde, özellikle şiddete yönelik davranışların gençler arasında yaygınlaşmasında medyanın 'etkili' bir rolü olduğu üzerinde durulur. Gaunlett (2008), çocuk ve medya çalışmalarındaki bu genel eğilimi "medya etkileri" yaklaşımlarının yaptığı 10 temel yanlış içerisinde sayar ve çocukların medya gösterilerine karşı en az yetişkinler kadar bilinçli, hatta alaycı olabildiklerini, düşünceli, eleştirel bir "medya okuryazarı" olarak görülmeleri gerektiğini belirtir. Medya etkileri yaklaşımları bugün, internet ve akıllı telefon bağımlılığı, yeni medyanın yaydı̆̆ı pornografi ve şiddet görüntülerinin etkileri bağlamında yeniden tartışılmakta ve dijital çağda da eleştiri konusu edilmektedir (Livingston, 2016).

Çocuk ve medya ile ilişkili çalışmaların diğer bir boyutunu içerikle ilgili olarak çocuk temsilleri oluşturmaktadır. Burada da iki ana eğilim göze çarpar: Birinci eğilim çocukların daha çok aile içerisindeki ve cinsiyet rolleri açısından nasıl temsil edildikleriyle ilgilenen kültürel çalışmalar geleneğidir (Hall, 1997). İkinci eğilimse basında, çocuk kitaplarında, edebiyatta, televizyonda ve 'haber programlarında' çocuklara biçilen toplumsal roller ve kimlik sunumlarıyla bağlantılı yapılan çalışmalardan oluşmaktadır (Lemish, 2015; Şirin, 2011; Durna, Kubilay, 2010; Aydın, 2009; Özmen, 2012). Bu çalışmalar, Livingston' in (2016) medya etkilerine karşı önerdiği "çocuk hakları" yaklaşımının bir uzantısı olarak sıklıkla Birleşmiş Milletler Eğitim, Bilim ve Kültür Örgütü (UNESCO) tarafından kabul edilen "çocuk hakları" metinlerine göndermede bulunurlar. Fakat bu metinler de bir şekilde kendine özgü bir 'çocuk' tanımı yapmaktadır: örneğin, UNESCO metninde, düşünceleri, aktiviteleri ve inançları dolayısıyla hiç kimse tarafından yargılanamayacak, cezalandırılma ve ayrımcılığa karşı korunması gereken 18 yaşından küçük tüm insanlar çocuk olarak tanımlanır. (UNESCO, 1989). Çocuk temsillerinin örneğin, Hall'un (1997) yaklaşımındaki gibi, ırk ve cinsiyet merkezli bir politik mekanizma tarafından 
hangi bağlamlarda ve ne gibi güç ilişkileri içinde sunulduğuna dair kapsamlı bir içerik analizi oldukça sınırlı sayıda üretilmiştir. Bununla birlikte özellikle reklamlardaki (Kalan, 2010), resim sanatındaki (Daşçı, 2008), filmlerdeki (Howe, Yarbrough, 2014; Pembecioğlu, 2006) çocuk temsilleri hakkında önemli çalışmalar yapılmıştır. Yine bu çalışmalarda ideal, olumsuz/kötü, mağdur, cinsiyet kimliklerinin kabulü anlamında prenses-prens ve masal karakterlerinin kullanımı gibi bir dizi çocuk temsilinden bahsedilmiştir.

Toplumsal algıda rahatlıkla kabul gören, çocukluğun da tıpkı diğer toplumsal sistemler gibi doğal değil kültürel, yani bir inşa sürecinin eseri olduğunu unutturan bir "doğal çocuk" imgesi oldukça genel ve yaygindır. Bu anlamda bu "doğal" çocuğun nasıl temsil edildiği ya da başka bir deyişle nasıl inşa edildiğine dair görüşümüz oldukça kısıtlı, yapılan çalışmalar da alabildiğine sinırlıdır. UNESCO metinine de yansıyan bu temsilde çocuklar, genellikle korunmaya muhtaç, geleceğe yönelik gelişimi desteklenmesi gereken, fiziksel ve ruhsal sağlığı kişi, kurum ve devletlerce güvence altına alınması gereken, herkes gibi iyi bir eğitim hakkı olan varlıklar olarak sunulurlar. Özellikle medya; dizilerden yarışma programlarına, haberlerden reklamlara bu 'doğal çocuk' imgesinin yayılmasına ve geliştirilmesine katkıda bulunur.

Tıpkı Laura Mulvey'in (2004) cinsiyet rollerinin bakışla yönetilen bir güç ilişkisi içerisinde dayatıldığına dönük "erkek bakışı" (male gaze) yaklaşımında olduğu gibi, bakış ve söylem yoluyla yetişkinin kendisini hakim ve güçlü kıldığı, yeni bir tür hiyerarşiyi doğallaştıran bir "yetişkin bakışı"ndan (adult gaze) söz edebiliriz. Türkiye'de prime-time dışı zamanlarda, ulusal bir kanalda, haftalık bölümler şeklinde yayınlanan Çocuktan Al Haberi yarışma programı da yetişkin bakışının en etkili örneklerinden birini sunar. Eğlenceli bir dille sunulan, çocukların sorulan sorulara verdiği komik cevaplara, program içerisinde yaptıkları taklitlere, anlattıkları masallara hatta verdikleri yemek tarifleri gibi performansa dönük temsillere dayanan program, bu "doğal" çocuk imgesinin yaygınlaşmasına katkıda bulunur ve yetişkinlerin bakışından kaynaklanan ayrımcılığı örtük hale getirir.

Bu çalışmada, tarih boyunca güç ilişkileri, kültürel kurumlar, yaygın inanç ve değerler ve sosyal ilişkiler çerçevesinde sürekli farklı tanımları yapılan çocuk kavramının Çocuktan Al Haberi programında nasıl temsil 
edildiği incelenecek; bunun için de yarışma programında kullanılan söylemlerin kapsamlı bir analizi ve programdaki görsel tercihler hakkında detaylı bir inceleme için şu sorular sorulacaktır: 'Yetişkincilik' (Adultism) ve yetişkin bakışı (adult gaze) nasıl tanımlanabilir? Çocuktan Al Haberi, çocukluğu nasıl tanımlamaktadır? Çocuktan Al Haberi'nin yansıttığı çocuk temsillerinde yetişkincilik (Adultism) ve 'yetişkin bakışı' söylemler ve görsel tercihler üzerinden nasıl yeniden-üretilmektedir?

Kültürel ve tarihsel bir inşa süreci olan çocukluk, anne-babaların zihinlerinde bir imge olarak yaratılmakta, bu imgelerse çocuğun kişiliğinin oluşmasında, davranışlarının biçimlenmesinde, algılama düzeylerinin gelişmesinde, geleceğe dönük hedef ve umutların belirlenmesinde önemli roller oynamaktadır (Ercan, 2014: 381). Çocuktan Al Haberi özellikle ebeveynlerin bilincindeki çocuk imgesinin yaratılmasında etkin bir rol oynamaktadır. Bu çocukluk imgesi çocukların kendi gerçekliklerinden değil, 'yetişkin bakışı'nın onlarda görmeyi arzuladığı, performatif, dışsal ve daha çok yetişkin dünyasının güç ve hakimiyetle ilgili beklentilerinden kaynaklanan yapıntı bir kimlikten besleniyor gözükmektedir.

Bu çalışma, medya ve çocuk ilişkilerinde pek üzerinde durulmayan bu mekanizmanın unsurlarını araştırarak toplumsal alg1 ve düşünüşümüzdeki bu boşluğu doldurmak ve konuya dikkat çekmeyi amaçlamaktadır. Konu dahilinde bir ilk çalışma örneği olacak bu araştırma, medya ve çocuk çalışmalarına 'yetişkin bakışı' (adult gaze) ve yetişkincilik (adultism) kavramlarının da tanıtılması açısından önemli olabilir. Bu çalışma medyadaki 'doğal' çocuğun Çocuktan Al Haberi örneğinde nasıl son derece gizli/örtük bir biçimde -ve çoğunlukla bilinçsiz bir biçimde- üretildiğini göstererek konuyla ilgili bir araştırma modeli de sunabilir.

\section{Gelişim Psikolojisinde Biyolojik Bir Evre Olarak Çocukluk}

Çocukluk öncelikle biyolojik bir olgu olarak kabul edilebilir; ilk bebeklik evresinden başlayarak sağlıklı bir yetişkin görünümü alana kadar geçen süredeki insan yavrularına çok genel bir bakış açısıyla çocuk denilebilir. Çocukluğun doğal gelişim süreci ve kat ettiği evreler en kapsamlı biçimde 20. yüzyıl başlarından itibaren gelişim psikologları tarafından ele alınmıştır. Gelişim psikolojisi teorileri belli başlı çocukluk tanımları yaparak bir çocukluk temsili oluşturur. Düşünce, dil, sosyal davranış veya algı gibi 
psikolojik ve zihinsel düzlemlerin zaman içindeki değiş̧imini anlamaya çalışan gelişim psikolojisi, çocukluğun ne olduğuna dair bize oldukça farklı tablolar çizmektedir (Miller, 1999, s.5). Gelişim psikolojisinde, çocukları gelişim süreçlerinde pasif varlıklar olarak değil, kendi gelişim süreçlerinin aktif ajanları olarak gören bir eğilim ortaya çıkmaya başlamıştır. "Çocuklar özümser, alışır ve denge bulur (Piaget); ego süreçleri güçlenir (Freud); bir kimlik hissi inşa eder (Erikson); ve kendi çevrelerini değiştirir ve öz-düzenleyici mekanizmalar geliştirirler (sosyal öğrenme). Buna ek olarak, kontrol süreçlerini (bilgi işleme) etkinleştirir, çevrelerini araştırır ve başkalarından tepkiler çıkarır (etoloji), kazanımlarına yönelik ortamları keşfeder (Gibson) ve belirli sosyal düzenleme türlerini (bağlamsalcılık) araştırırlar" (Miller, 1999, s.426-427).

Gelişim psikolojisi ve çocukluğun biyolojik evrimi üzerine çalışmaların başında Freud'un eserleri gelmektedir. Freud'a (2015) göre çocukların cinsel yaşamı gözlemlenebilir olarak üç ya da dördüncü yaşlarda ortaya çımaktadır. Hemen ardından tiksinti, utanç ile estetik ve moral ülkülerin istemleri tarafından bu dürtüler bastırılır ve ket vurmalar başlar. Fakat bu ket vurmalar sadece eğitimin rolüyle değil organik gelişme ve kalıtım tarafından da belirlenmektedir. Çocuksu cinselliğin dışavurumlarını inceleyen Freud, parmak emme gibi çoğu oto-erotik cinsel dışavurumların yetişkinlikte cinsel organlara doğru genişlediğini belirterek aslında bir gelişimsel dönem ortaya koyar. Hatta yetişkinliğe ilk adımlar da bu cinsel aktarımın yabancı, örtük doğasından kaynaklanır gözükür. Freud çocukluğun bu ilk dönemindeki cinsel merak ve araştırmaların tam bir yalnızlık içinde gerçekleştirildiğine, bunun da çocuğun dünyaya karşı bağımsız bir tutum alması, daha önce ebeveynleriyle tam bir güven ilişkisi içinde olduğu ortama ileri derecede yabancılaşması için bir ön şart olduğuna dikkat çeker (2015, s.108). Yetişkin birey, çocuklukta bir bastırma ve gizlilik evresinden geçen cinsel uyaranlarını artık oto-erotik bir bağlamdan uzaklaştırarak doğrudan nesnelere yöneltmektedir. Freud'un çoğunlukla çocuklarla ilgili gözlemlerinden çıkarsadığı insan psikesinin yapısı ve diğer yaklaşımlar bugün psikanalitik kuramın temellerini oluşturmaktadır. Bilinçaltı, ego ve süper-ego oluşumları farklı kuramcılar tarafından farklı bağlamlarda kabul edilip yeniden üretilse de yöntemleri ve çocuklukla ilgili gözlem tarzı eleştiri konusu edilmektedir. "Freud'un oyun incelemesi 
metodu Victoryendi, soğuk, hemen hemen dikizcilik sınırındaydı. Notlarını ayakta, yarı gizli, bir kapının arkasında ya da -en azından bildiğimiz kadar- çocukla çömelip oynamadan anneyle söyleşi yaparak, göz teması kurmadan tuttu" (Slade, Wolf, 1999, s.6). Slade ve Wolf'a (1999) göre, ket vurmalar ve aktarımları yansıtan çocuk etkinlikleri aslında gözlemlenerek değil ancak performansa katılarak anlaşılabilmektedir.

Piaget (2000) ise çocukluğun ilk evresini bebeğin henüz dilden yoksun olduğu, bilişin, duyu ve hareketin şekillendirişiyle oluştuğu bir duyu-motor evresi olarak tanımlar (sensori-motor stage). Bu aşamada hiçbir sembolik alan mevcut değildir; bebeğin kişilik temsilleri yoktur. İlk aşamada, uyaranlara karşı geliştirilen refleksler, ardından gelecek yeni durumlara karşı bir takım alışkanlıkların oluşmasına zemin hazırlarlar. Yeni doğanın bu ilk evrelerini aşama aşama anlatan Piaget, bir buçuk iki yaşlarında yeni bir davranış modeli olarak çocuğun nesne, olay ya da kavramsal şemalar gibi şeyleri temsil edebildiğini, yani bir gösteren gibi hareket ederek dil, zihinsel imajlar ve sembolik jestler sunabildiğini belirtir. Bu bir anlamda taklit evresidir; çocuk oyun arkadaşlarının kızgınlık, çığlık, ayağını yere vurma gibi davranışlarını taklit eder, kedi sesi çıkarır, grafik imajlar çizer vb. 2 yaş sonunda, cinsel ilgiler, kayg1, fobi, öfke veya saldırganlıkla karışık savunma, rekabet veya güvenlik kaygısından kaynaklanan bir tür sembolik oyun mekanizması, sembolik taklit evresi gelişir; Piaget bu döneme işlem öncesi dönem (pre-operational stage) adını verir. Burada çizimler, hayali imajlar devreye girebilir. 7 yaşından 12 yaşına kadar gelişen somut işlemler dönemindeyse (concrete operational stage) çocuk artık somut dünyayla etkileşim içinde zihinsel kategorilerini geliştirebilmektedir. Piaget'nin çizdiği işlem-öncesi dönem Çocuktan Al Haberi gibi 3-5 yaş grubundan çocukların konu edildiği bir programı analiz etme amacındaki bir çalışma için özellikle önemlidir. Çünkü tıpkı programda sıklıkla yapıldığı gibi bu dönemdeki çocuklar, büyük gibi konuştuğu, motor hareketleri geliştiği vb. için "'büyümüş çocuklar" olarak görülebilmektedir. Piaget'nin (2000, s.177) verdiği örnekten gidersek, 4-5 yaşlarındaki çocuklar, belki 10 dakikaya kadar mesafelerdeki okullarına tek başına ve yürüyerek gidip gelebilirler. Fakat onlara her gün geçtiği yolu ya da ana girişten göründüğü gibi okulunun planını üç boyutlu olarak tarif etmesini istersek bü- 
yük ihtimalle başarısız oluruz. Çocuk her gün aynı eylem içinde bu yolları, mekanları ve araçları somut olarak kullansa da mekanla kurduğu topoğrafik ilişkiyi inşa etmekte yetersizdir.

Çocukluk sadece bir biyolojik evre ya da zihinsel gelişim aşaması olarak düşünülemez; çocukluk aynı zamanda bir kültürel anlayıştır ve sadece belirli dönemler için değil, aynı çağı paylaşan farklı toplumlar için de farklı anlamlar taşıyabilir. Bu sebeple çocukluğun kültürel inşası biyolojik kavrayışın önüne geçmektedir.

\section{Çocukluğun Kültürel İnşası}

Batılı anlamda çocukluğun kuruluşu ya da günümüzde anladığımız ve belirli kodlarla günlük yaşantı içerisinde (ve medya gösterilerinde) temsil ettiğimiz 'doğal' çocuk örüntüleri, 16. yüzyılın başlangıcına kadar geri götürülebilecek bir geçmişe dayanır. Bu doğal çocuk imgesi çeşitli kesinti ve süreklilikler içerisinde sanayii devriminin karanlık sonuçlarında hayatta kalacak ve nihayetinde Rönesans'ın bir düşlemi olarak insan doğasının henüz bozulmamış, kirlenmemiş bir saf ilk-imgesi olarak zihinlere yerleşecektir. Kant "What is Enlightenment?" adlı denemesinde, uygarlığı eğitilmesi gereken çocuksu bir varlık olarak görmekte, uygar toplumu "erginleşmiş" bir toplum olarak kutlamaktadır (Kant, 2009). Çocuğu bir tür doğal insan olarak gören Rousseau'ya (2016, s.110) göre çocukların gereksiz güce sahip olmak şöyle dursun, doğal ihtiyaçlarını karşılama gücüne dahi sahip olmadığını, dolayısıyla güçlerinin engellenmemesi gerektiğini, buna karşın zekada, güçte, bedensel gereksinim nitelikli her şeyde yardıma ihtiyacı olduklarını belirtir. Fakat bu tür bir çocuk birkaç yüzyıl daha geriye gidildiğinde var olmayan bir 'doğal' çocuk anlayışını yansıtmaktadir. Fatih Sultan Mehmet Osmanlı Devleti'nin, Romulus Agustus ise Batı Roma İmparatorluğu'nun başına geçtiğinde henüz 12 yaşındadır ve devlet yönetiminde karar alma mekanizmalarıyla bugün 'çocuk' denilebilecek yaşta tanışmışlardır.

Çocukluğun bir kavramsal inşa süreci olarak tarihiyle ilgili çalışmalar, bu alanda en çok atıf yapılan isimlerden olan Fransız tarihçi Philippe Ariès'in 1962 tarihli çalışması Centuries of Childhood'a dayanır. Ariès'e göre, Ortaçağda herhangi bir çocukluğa yer yoktur. Bu yaklaşımı, döne- 
min resimlerinde 12. yüzyıla kadar hiçbir çocuk imajının olmayışı ve minyatür sanatı içinde çocukların yetişkinlerle benzer kıyafetler giyen, benzer fiziksel görünüşlere sahip "küçük insanlar" olarak temsil edilmesi gibi olgulara dayandırır. Bunu bir ihmal ya da yetersizlikten çok 'çocuk kavramının' yokluğuna bağlayan Ariès, 20. yüzyılın ilk yarısı boyunca süren psikanalizin yükselişi ve gelişim psikolojisinin tanımladığı çocukluk imgesinden çok farklı bir portre çizer ve çocukluğun bir sosyal inşa süreci olarak görülmesi fikrini ilk defa ortaya atar.

Heywood'a (2001) göre Ariès, çok geniş bir bağlamda değerlendirilebilecek çocukluk kavramını sadece resim ve minyatür sanatındaki yokluk üzerinden açılamaktadır. Ortaçağ resmi sadece çocukluğu değil kutsal hikayeler ve dini konular dışında pek çok şeyi de resmin dişına itmiştir. Üstelik Heywood'a göre Ariès Orta Çağ'da hiçbir çocukluk bilinci olmadığına dair fazla kolaycı açıklamalar yapmakta, çocukluğun özel bir doğası olduğuna dair düşüncelerin varlığı yok sayılmaktadır. Örneğin Orta Çağ'da çocukluk, doğumdan 21 yaşa kadar üç aşamaya ayrılmaktadır. Cunningham (1996, s.27), Orta Çağ tıbbında bazı çocuk hastalıklarının, yetişkinlerden ayrı ve farklı ele alındıklarını, 7 aylıktan 2 yaşına kadar aciz ve bağımlı, yetişkinlerden çok şey bekleyen, oyun oynayabilecek varlıklar olarak görüldüklerini belirtir.

Dinler içerisindeki çocuk imgelerinin izini süren Sandler'e (1996) göre çocukluk hemen hemen tüm dinlerde yetişkinlikten farklı bir varlık olarak temsil edilmektedir. Örneğin, çocukların yetişkinlerden farklı sosyal, yasal, dini ve cinsel hak ve zorunlulukları vardır. Onların sosyal, dini ve etik davranışları yetişkinlerden farklı bir biçimde değerlendirilir. Buna karşılık doğuştan gelen özellikleri bakımından çocuk, örneğin İslam' da saf, günahsız doğarken Hıristiyanlık için günahla ağır bir biçimde kirlenmiş, atalarının günahlarıyla lekelenmiş olarak doğduğu kabul edilir. Böylelikle birinde tıpkı bir fidan gibi çocuğun doğal gelişimi için uygun bir çevre, doğru bir toprak anlayışı anlamında ebeveynin rolü pedagojinin merkezine otururken, diğerinde çocuğun doğal istek ve eğilimlerine karşı mücadele etmeyi öğretme anlamında denetim çocuğun yetiştirilmesinde merkezi bir önem kazanmıştır. Yine de hemen hemen tüm dinlerde Tanrı, bir baba, insanlarsa onun çocukları olarak görülür. Bu bakışın farklı yorumları ve çeşitlemeleri olduğu kadar 'Baba ve evlatları' imgesi neredeyse evrenseldir. Freud'a göre (2002) dinin ve tanrı fikrinin kökenlerinde ilkel 
klanda babayı katleden, sürüden atılmış evlatların suçluluk bilinci vardır: "herkesin tanrısı kendi babasının suretindedir" (2002, s.204). Çocuk imgesi, masumiyeti, alçak gönüllülüğü, saflı̆̆ı, merakı, hassasiyeti, tazeliği, hesaplanamazlığı, basitliği, dar ihtiras ve amaçlardan yoksunluğu ve az çok benzer yüce değerle ilişkilendirilir. Fakat aynı zamanda benmerkezcilik, hamlık, kararsızlık, bönlük ve bilgelikten uzaklık gibi dini yaşamda üstesinden gelinecek özelliklerle de temsil edilir.

Günümüzdeki çocukluk imgesinin kökenlerinde modernite olgusuna bağlı dinamikler yatmaktadır; 17. yüzyılın ilerleyen dönemlerinde, eski kullanımların daha bağımlı toplumsal sınıflarda sürerken orta sınıfta kelimenin modern anlamıla bir 'çocuk' yaklaşımına dönük farklı bir kullanımın ortaya çıkmaya başladığı görülür. Çocukluk fikri, bağımlılık fikrine bağlanır: "oğullar", "uşaklar" ve "oğlanlar" kelimeleri boyun eğme sözcükleri olarak kullanılır. Bir kişi çocukluktan sadece bağımlılık durumu sona erdiğinde kurtulur ya da en azından bir miktar bağımsızlık kazanması gerekir (Ariès, 1962, s.26). Türkçedeki "evladım" ya da "oğlum" seslenişlerine benzer kullanımlar biyolojik bir evreye işaret etmemektedir. Feodal boyun eğdirmenin bir parçası olarak kullanılmaya devam eden ve bağımlılık fikrinin bugün de yaşamasını sağlayan bu tip söylemler "güle güle evladım" ya da "çocuk, git bana şunu yada bunu getir!" gibi emir ve sesleniş cümlelerinde yeniden üretilmektedir. Bu anlamda aslında çocukluğun kuruluşu modernitenin yeni bir güç ilişkisi tarifi olarak da görülebilir. Heywood'a (2001) göre çocukluk, biyolojik bir gelişim evresine işaret etmekle birlikte, tarihsel, coğrafi, ekonomik ve kültürel yapılar tarafından yeniden tanımlanarak dikkat çekici ölçüde yetişkin beklentilerinin bir fonksiyonu olarak inşa edilmektedir.

Holland'a (2004) göre ise çocuklar, yeni inşa edilen orta sınıf gettolarında, ticaret ve çalışma dünyasından izole edilmiş evlerde, korunaklı bir yaşamın parçası haline getirilmiş, çocuklarla evde vakit geçirmek eğlenceli bir boş zaman aktivitesine dönüşmüştür. Çağdaş çocuk imgesini anlamak için 19. yüzyıl ortalarındaki yeni müreffeh orta sınıf arasında kök salan bir korunaklı çocukluk imgesine bakmak gerekmektedir. Holland bu modern çocukluğun bir tür 'yetişkin bakış1' çerçevesinde inşa edildiğinden bahseder. Yetişkin bakışı, çocukları onlardan beklenen mekanlara yerleşmeye ve onlardan beklenen desenlere uydurmaya çalışır. Bakışın 
ikili bir yönü vardır: keyif ve güç. Güç yetişkinlerin yaşam hakkındaki üstün bilgilerinden gelir, keyifse çocukluğun güzelliği ve etkileyiciliğinden. Yetişkin bakışına göre, çocuklar bu gücü kabul etmeli ve keyif vermelidir. Masumiyetlerinin parıldamasına izin vermelidir. Ancak, yine Holland'a göre, romantik masum kültü, çocukluğun çürümesiyle ilgili endişe yaratmaya başlarken, çocuk hayatının tüm dünyada yapılacak bir rasyonel araştırması her gün, genelde aşağılayıcı ve derinden şok edici koşullar ortaya koymaktadır. Çocukluk, her zamankinden daha fazla değerlidir, ancak ya kriz halinde ya da ölmekte olarak algilanmaktadır (2004, s.9-12).

Bu bakış açısı Neil Postman'ın Çocukluğun Yokoluşu'nda (1995) kapsamlı bir biçimde savunulmaktadır. Postman'ın 'medya etkileri' alanında görülebilecek çalışması, çocukluğu matbaanın bulunuşuyla ortaya çıkan ve elektronik çağda yok olan bir sosyo-kültürel olgu olarak ortaya koymaktadır. Postman'a göre hareketli matbaa yeni bir simgesel dünyayı yaratarak "çocukluk" düşüncesinin oluşmasını sağlamış, çocuklar yetişkin dünyasından kovularak, onlar için tasarlanan simgesel bir evren olarak 'çocukluk dünyası' na hapsedilmiştir. Yetişkinler çocukların simgesel çevresi üzerindeki üstünlükleriyle ve onların da yetişkin olabilmesinin koşullarını yaratarak çocukluğu inşa ederler. "Güçlü bir bireysellik duygusu, mantıksal ve ardışık olarak düşünebilme kapasitesi, üst düzeyde soyutlama yetilerini yönlendirebilme kapasitesi, haz duygusunu erteleme kapasitesi" (1995, s.62). Bunlar, çocuğun öğrenmesi ve uygulaması gereken yetişkinlik göstergeleridir. Böylece çocukluğun enerjisi de bastırılarak, ayıp kavramı çerçevesinde yeni bir uygarlık şeması da oluşturulmaktadır. Tipografiden elektroniğe geçişle birlikte yetişkin dünyasının sırları ortaya saçllmış, yetişkinlik ve çocukluk arasındaki sınırlar belirsizleşmiştir. Alver'e (2004) göre, Postman'ın çocukluğun (tıpkı kitap gibi) yok oluşuna yaklaşımında elektronik öncesi çağa karşı nostaljik bir bakış açısı yatmaktadır. Postman, orta sınıf çocukluk tasarımını merkezine almış, çocukluğun zirvesi olarak gördüğü sanayii çağında çocukların çok ağır koşullarda çalıştırıldığını göz ardı ettiği için eleştirilmiştir (2004, s.137). Postman'ın yetişkinlerin simgesel evrenini yayıp demokratikleştirerek çocukluk kavramını gereksizleştirip yok ettiğini belirttiği televizyon, Çocuktan Al Haberi gibi programlar bağlamında tam tersi amaçlarla da kullanılabilmektedir: modern çocuğun yeniden üretimi. 


\section{Türkiye'de Çocuk}

Türkiye'de çocukluğun tarihi elbette kökleri Osmanlı İmparatorluğu'na uzanan köklü bir gelenekten beslenmektedir. Ancak çağdaş Türkiye'nin benimsediği ve yücelttiği çocukluk ideali Cumhuriyet'le birlikte başlamaktadır.

Öztan'a (2011) göre, Batılılaşma projesi çerçevesinde, çocuklara 'geleceğin teminatı' olarak büyük bir rol biçilmiş, eğitim ve öğretim alanındaki inkılaplarla cumhuriyetçi kuşaklar yaratılması, yeni rejimin vadettiği modernleşme ve kalkınma ideallerinin korunması sağlanmak istenmiştir. Bu anlamda, sadece çocukların değil, yetişkinlerin eğitimi/terbiyesi de ön plana çıkmış, tüm yurttaşlar aslında birer öğrenci olarak görülmüş, bir anlamda çocuklaştırılmıştır. Bu açıdan bakıldığında yurttaş olmak da devlet babanın evlatları olmak anlamında bir tür kendi içinde çocukluk barınd1rır. Tıpkı çocuklar gibi yurttaşın kendisi de Cumhuriyet değerlerini geleceğe taşımak için eğitime önem vermeli, kendisini yetiştirip geliştirmelidir.

Cumhuriyet çocuğunun inşa edilmek istenen en temel özelliği medeniliğidir; Öztan'a göre tıpkı cumhuriyetin kendisi gibi çocukluk da "daha çok biçimsel göstergeler ile temsil edilen" hatta çoğu zaman eş tutulan bir medeniyet projesidir (2011, s.68). Öztan, çocukların terbiyesi, kamusal alanda davranışlarına dikkat edişi, kıyafet ve temizliğe verdiği önem gibi uygar toplumlara atfedilen bir dizi titiz kimlik inşasından bahseder. Çocuğun bu tür pozitif nitelikleri bugün de yaygın toplumsal inanışlara karşllık gelmektedir. Bununla birlikte çocukluğun Cumhuriyet dönemindeki politik inşasına dair birçok ayrı başlık sayılabilir; örneğin 1929 krizini takip eden yıllardaki tasarrufçu ekonomik programın getirdiği "kumbara", iktisat ve tasarrufun çocukluk dünyasındaki simge objesidir (s.97). Kimi zaman padişaha sadakat, kimi zaman Tanrı korkusu, kimi zamansa ideal yurttaşlık görevi olarak dürüst ve çalışkan olmanın erdemi (s.104); cehalete karşı okumanın önemi (s.110); Batı jargonundaki "hasta adamı" unutturacak güçlü ve sağlıklı çocuklar yetiştirilmesi zorunluluğu (s.128) gibi bir dizi imgeden bahseder. Tüm bu temsil biçimleri hem bir inşa çabasına işaret eder hem de idealleştirilen çocuk imgesinin cumhuriyetin ilk yıllarindaki bir portresini sunar. 
Kağıtçıbaşı'na (1981) göre Türkiye' de çocuk her zaman ailenin bir parçası olmuş, bu sebeple de bir doğa kanunu gibi görülerek çocuk yapılmıştır. Yine de ebeveynler tarafından çocuklara bir değer verilmektedir. Geleneksel değerler ile modern ailenin çocukluk algılarındaki farkını 80'lerin başında kapsamlı bir portreyle ortaya koyan Kağıtçıbaşı, geleneksel ailelerde çocuğun aileye ekonomik ve manevi anlamlarda yardım etmesinin, kentli ailelerdeyse çocukların yaşama keyif katan, başkalarına gösterilecek, başarı hissi veren, kişilik geliştirici yönlerinin ön plana çıktığını belirtir.

Televizyon temsillerindeki çocuklar doğası gereği belirli bir performans açısından değerlendirilmek zorundadır. Onları izleriz ve kim olduklarını bize sundukları göstergeler üzerinden değerlendiririz. Günümüz kültürü bu anlamda oyunun kendisini de bir tüketim faaliyeti haline getirerek yozlaştırmıştır. Kendi başına bir amaç olması gereken oyun eylemi giderek nesnelere yöneltilmiş, geçmişin sokak oyunları, sokak kavgaları, başkalarıyla oynama anlayışı unutulmuştur. "Özünde eğlence olan her şey günümüzde ticarileşmiş ve yarışma konusu haline gelmiştir" (Onur, 2005, s.39).

\section{Medya Çalışmalarında Çocuk Araştırmaları}

Çocuklar hakkındaki yaygın toplumsal inanç onların toplum ve dünyanın geleceği olduğu yönünde; dolayısıyla onları korumak, sevmek, değer vermek ve yarınlara hazırlamak da yine yaygın bir ideal. Fakat bunu yaparken yetişkinler çocukların kendine dönük temsillerini oluşturmadaki yetersizliklerinden faydalanabilmekte, yöntemleriyle baskıcı bir yapı kurup gizli bir zorbalığ1 yürütebilmektedir. Tıpkı rrksal ve cinsel güç ilişkilerinde olduğu gibi, sözü çocuklardan alıp onlar adına konuşup, onları kendi görsel hazzına dönük performanslarıyla değerlendirebilmektedir. Dahası yetişkinler çocukların çaresizlik ve masumiyet temelli temsilleri aracılığıyla kendi yetişkinlik ve tamamlanmış benlik kavrayışını oluşturuyor olabilir. Oğuz'a (2000, s.33) göre, televizyon gösterileri bu etkileşimi oluşturabilme gücüne sahiptir. Çünkü TV'den yayllan mesajlar bireyin toplumdaki rolleriyle ilgili algılamaları oluşturan kültürel yargıların ve değerlerin aynasidir. 
Televizyon ve çocukla ilgili araştırmalar sıklıkla televizyon çalışmaları alanının dışına çıkmak durumunda kalır. Çünkü çocukluğun kendisi dini görevlilerden politikacılara, psikologlardan sosyal bilimcilere, öğretmenlerden ebeveynlere çok farklı alanlardan birçok kimseyi ilgilendirmekte ve her alan kendi söylemini inşa etmektedir (Casey, Casey, Calvert, French, Lewis, 2008, s. 30). Bu anlamda yapılan çalışmalar geniş bir yelpazede değerlendirilebilir. Birçok çalışma çocukların istenmeyen materyallere erişimiyle (şiddet, seksüel içerik ya da argo/küfürlü konuşma), medya organlarının ya da yetişkinlerin çocuklara uygun içerikler sağlamalarına dönük sorumluluklarıyla, program içeriklerinin ahlaki ve etik uygunluğuyla ilgilidir. Bir çoğuysa eğitimle ilgili konular bağlamında (eğer mümkünse televizyondan ne öğrenebilirler?), tüketim sorunu (çocuklar televizyon aracılığıyla piyasa güçleri tarafından etkileniyor mu?) ve yaratıcı oyunlar ve okuryazarlık standartlarını erozyona uğratan medya gösterileri çevresinde tartışılmaktadır (2008, s.31-32).

Çocukların televizyonda nasıl temsil edildiğiyle ilgilenen çalışmalardaysa temsil ile gerçek arasındaki uçurum çalışmaların merkezinde yer almaktadır. Yine de Arnett (2007), medyadaki çocuk temsillerini inceleyen çalışmaların sınırlılığından bahseder. Arnett'e göre, çocukların medyadaki temsil ediliş biçimlerini araştıran çalışmalar 3 başlık altında sıralanabilir: Cosby Ailesi ve Simpsonlar gibi televizyon ailelerindeki çocukların imajları üzerine yapılan daha çok aile araştırmalarının bir parçası olarak çocuk temsillerine değinen çalışmalar (1), çocukların medya temsillerinde cinsel farklılıklarına göre, örneğin rasyonel-irrasyonel, aktif-pasif, saldırgan-duyarlı, mutsuz-mutlu gibi ikili sıfatlara göre, nasıl farklı biçimlerde temsil edildiğini araştıran çalışmalar (2) ve daha çok filmlerdeki gençlik temsillerini içine alan diğer çalışmalar (3) (2007, s.158).

Türkiye'de medya, TV programları ve çocuk ilişkileri en çok etkilenimler açısından ele alınmaktadır. Sakıncalı bulunan içeriklerin sansürlenmesi, içeriklere uygun belirli yaş gruplarının gündeme getirilmesi söz konusudur. Sadece ebeveynler için değil devlet politikaları açısında da çocuk-medya ilişkileri yine kullanımlar açısından ele alınmaktadır. İnternetin yaygin bir şekilde sosyal yaşama girişiyle birlikte bu kez internet kullanımı ve güvenli internet sorunu ortaya çıkmıştır. Geleneksel medya içeriklerinin aksine, internetin denetlenmesi çok daha zor olduğundan çocuk güvenliği açısından yaş kilitleri gibi uygulamalar gündeme getirilmiştir. 
Bilgisayar ve internet kullanımı, 2018 yılında \%72.9 olmuştur. Her on hanenin sekizi internet erişimine sahiptir (Türkiye İstatistik Kurumu [TUIK], 2018). TUIK'nun çocuklarda bilişim teknolojileri kullanımı ile ilgili yaptığı son araştırma 2013 yılına aittir ve 06-15 yaş gibi geniş bir aralığı kapsamaktadır. Karakuş, Çağıltay, Kaşıkçı ve Organ'ın 2014 yılındaki araştırması bu anlamda en kapsamlı araştırmalardan biridir. EU Kids Online projesi tarafından desteklenen çalışmada Türkiye genelinde 2000'e yakın çocuk ve ebeveyn ile birebir görüşmeler gerçekleştirilmiş, Türkiye'deki çocukların \%36,2'sinin günde ortalama 1 saat internet kullandıkları tespit edilmiştir. Bu oran Avrupa'nın çok altındadır ve internet riskleri de bu anlamda düşüktür. Yine de örneğin, cinsel içerikli görüntü ya da mesajlara maruz kalmaları oranının gerçekte daha yüksek olduğu beklenmektedir.

Türkiye'de çocukların reklamlar, yazılı basın, TV haberleri gibi medyalardaki temsilleri araştırma konusu edilmiştir. Kalan (2010), reklamlardaki çocuk imgelerini, çocuklara yönelik üretilen Kinder çikolataları reklamları üzerinden incelemiş, reklamlarda erkek ve kız çocuklarının ayrı imgelerle temsil edildiği, toplumsal cinsiyet rollerinin kalıplaşmış rol modellerinin bu reklamlarda yeniden-üretildiği bulgulanmıştır. Tutar (2014), yazılı basındaki çocuk temsillerine odaklanarak ana akım medya içinde yer alan gazetelerden rastlantısal olarak derlediği haberlerde çocukların statüsünü olumlayan, cinsel tacize ve suça konu oldukları haberleri incelemiştir. Çocukların haberlerde genellikle edilgen-pasif olarak yetişkinlere göre alt bir konumda, yetişkinlerin onlara sağladığı kültür sanat etkinliklerinin pasif alımlayıcıları olarak ya da eğitim alanındaki haksız uygulamalara maruz kalmış kişiler olarak temsil edildiklerini bulgulamıştır. Özmen (2012), televizyon haberlerindeki temsillerle ilgili çalışmasında çocukların genellikle şiddet, suç ve hastalık içeren haberlere konu olduklarını tespit etmiştir. Çocuklar çoğunlukla şiddet ve kazaya maruz kalmış pasif ve sessiz kurbanlar olarak, hasta ya da engelli olmadıklarındaysa tehlikenin bizzat kaynağı ve öznesi olan suçlular olarak temsil edilmektedir. Aydın (2009) tinerci çocuklar örneği üzerinden giderek bu çocukların nasıl bir korku nesnesi haline getirildiğine dikkat çeker. Çoğunlukla kente göç etmiş Kürt çocuklarının tehlikeli "yabancılar" olarak temsil edildikleri bulgulanmıştır. Güven (2004), dizilerdeki çocuk temsilleriyle ilgili doktora çalışmasında çocukların belirli iktidar yapılarının üretilmesi ve 
sürdürülmesinde, belirli mesajların topluma iletilmesinde bir araç olarak kullanıldıklarını, devlet kurumlarının meşrulaştırılıp, iyi ailenin tanımlanarak belirli değerlerin oluşturulduğunu bulgulamıştır.

Gazeteler, TV haberleri, reklamlar ve diziler üzerinden yapılan tüm bu çalışmalar genel olarak değerlendirildiğinde çocuk temsillerinin sıklıkla yanlış ve kusurlu bulunduğu söylenilebilir. Toplumsal değer yargıları, inanışlar ve tutumların belirlediği ön yargıların medya temsillerine de yansıdığı, toplumsal cinsiyet rollerinin bu temsillerde yeniden üretildiği ve çocukların sıklıkla yetişkinlerle ilişkili olarak pasif ve sessiz varlıklar olarak ele alındığı, kurban ya da mağdur olarak gösterildiği, aktif temsillerde ise çocukların ya suçlu olarak kötülendiği ya da yüce değerlerin taşıyıcıları olarak idealize edildiği belirtilebilir.

\section{Medya Temsillerinde Yetişkincilik (Adultism) ve Yetişkin Bakışı (Adult Gaze)}

Yetişkincilik (Adultism) terimi gerek medya çalışmalarında gerek psikoloji alanında genel kabul görmüş ve yaygın olarak kullanılan bir kavram değildir. Terim Türkçe literatürde bulunmamaktadır. Bell (1995), yetişkinciliğin diğer izmlerin aksine (racism, sexism vb.) çocuklara bir tür kötü davranma ve saygısızca muamele etme konsepti olarak henüz geniş çevrelerce kabul edilmiş bir kavram olmadığına dikkat çeker. Ancak görüleceği üzere kavram modern toplumlarda gizli ve yaygın bir davranış örüntüsünü başarıyla açıklamaktadır.

Jack Flasher, 1978 tarihli makalesinde öncelikle dönemin ruhuna uygun bir şekilde gençlerin alkol ve uyuşturucu kullanımı açısından nasıl yargılandıklarına dikkat çeker. Bu tür kötüye kullanımlar dahil çocukların tüm bilinçsiz kullanımlarının onları "zayıf" olarak tanımlamada yetişkinler için bir köken oluşturduğunu belirtir. "Bu davranışlar yetişkinlerin diğer yetişkinlere karşı ırkçı, cinsiyetçi ya da elitist davranışlarına benzer. Çocukları sanki başka bir canlı türü gibi çok farklı olarak görmek yetişkinlere çocuklar üzerinde haksız bir güç kazandırır' (1978, s.517). Flasher yetişkinlerin çocuklar hakkındaki bu tip davranışlarına gönderme yapmak için Adultism (Yetişkincilik) terimini kullanır. 
Yetişkinlerin iktidarlarını yasal ve sosyo-ekonomik güçlerine, haklar ve imtiyazlarının genişliğine, fiziksel güçleri ve gelişmişliklerine ve çocukların bakım ve ihtiyaçlarını karşılama pratiklerine dayandırılabilir. Ebeveynler ya da yetişkinler bu güçlerini çocuklar üstünde kullanırken çoğu zaman bilinçsizce davranır. Çünkü yetişkinlerin çocuklardan daha üstün olduğuna dair bir inancı paylaşırlar (1978, s.517). Bu tip bir yaklaşımı öğretmenler, dini görevliler, hukukçular ve psikoterapistler sürdürerek yaygınlaştırır ve sıklıkla çocukluk imajı hakkındaki belirleyici güçlerini gizlerler. "Çoğu yetişkin çocukları temelde benzersiz biyolojik eğilimler ve biricik deneyimler olarak algılamaya çalışmak ve onların kendi olmalarına ve evrimlerine yardım etmek yerine çocuklara polislik yapmakla meşguldürler" (s. 518). Yetişkinler çocukları kafalarındaki bir imaja uygun hareket etmeye ve bir kalıba sokmaya çalışırlar. Bu aslında yetişkinlerin aşırı kendini önemseme ve haklı bulma niteliklerini gizleyerek bir anlamda yetişkinin kendisine yönelik telkin verme biçimidir. Çocuğun sadece kendine özgü evrimine değil, bağımsız bir bireye dönüşmesine karşı da bir kayıtsızlık ve duyarsızlık anlamında Yetişkincilik çok yaygın bir davranış örüntüsüdür. Çocuğun zayıflığını, güvenini, romantizmini ve idealleştirmelerini kötüye kullanma anlamında Yetişkincilik bir tür çocuk istismarıdır. Bununla birlikte çocuklar yetişkinlerin bu tür davranışlarına boyun eğerek, kendi kendilerini çocuklaştırarak, bir tür "Çocuksuluk" (Childism) üretebilirler (s.519).

Bell'e (1995) göre, yetişkincilik yetişkinlerin çocuklardan daha iyi olduğu varsayımına dayanan tavır ve tutumlara gönderme yapar ve çocukların rızası olmadan gerçekleşen bu tip davranışları ifade etmede kullanılır. Hapishane mahkumları dışında çok az grup çocuklar kadar kontrol altında tutulmaktadır. Irkçılık, cinsiyetçilik, yoksulluk, fiziksel ya da zihinsel engellilik ve benzeri başkaca faktörlere de dayanan bir dizi kötü davranış ve saygısızlık sayar: Çocukların özgüven ve öz-saygısını baltalamak, hakir görme, güçüzz görme, yıkıcı yaramazlar olarak görme, ciddiye almama, kendilerine zarar veren (hastalanan, intihara kalkışan, depresyona giren) varlıklar olarak görme gibi bir dizi pratik sayar. Fakat diğer bütün sebeplerin yanında Yetişkincilik, yıllara yayılan en basit ve sistematik, en gizli değersizleştirmelerden biridir. Bell bir çeşit söylem analizi yaparak adultism'i yansıtan deyişleri sıralar: "yaşına göre oldukça zekisin!", "dokunma kıracaksın!", "ne zaman büyüyeceksin?", "çocukluk yapma", 
"bunu anlayacak kadar büyük değilsin", , Ne biliyorsun? Daha hiçbir şey yaşamadın”' bu söylemlerden bazılarıdır (s.2). Flasher gibi Bell'de birçok alanda Yetişkincilik görüngülerine rastlanabileceğini belirtir. Çocuklar, örneğin okullarda hiçbir hayati kararı veremezler; öğretmenleri tarafından eleştirilir, puanlanır ve değerli ya da değersiz olarak sınıflanırlar (s.3).

İmajlarda çocukların temsil ediliş biçimlerinden bahseden Holland (2004, s.9) 'yetişkin bakışı' (adult gaze) kavramını kullanır. Yetişkin bakışı, çocukları onlardan beklenen mekanlara yerleştirmeye ve beklenen desenlere uydurmaya çalışmakta, bir tür keyif ve güç ilişkisi tesis etmektedir. Holland bir derslikte gülümseyerek parmak kaldıran, öğretmeninden söz hakkı isteyen çocukların resmedildiği Sovyetler Birliği'nden 1930 tarihli bir çizimi ve 1970'lerin İngiltere'sinden bir dersliği betimleyen iki imaj1 analiz eder. Öğretmenler imajlarda resimsel mekanın dişındadır. Çocuklar önlerindeki kitap ve defterlerine değil onları değerlendirecek, eleştirecek ve yargılayacak olan öğretmenlerine, yani resimsel mekanın dışına yöneltilmiş arzu dolu bakışlarla betimlenmişlerdir. Bu imajlar çocukları hem sempatik hem de yetişkinlerin bilgisine sahip olmayan güçsüz varlıklar olarak konumlarlar (s.76). Yetişkinler ve çocuklar arasındaki bu tip bir güç ve hakimiyet ilişkisi imajlar söz konusu olduğunda bakış yoluyla örgütlenmektedir. Çocuğun temsili, yetişkini ona belirli bir türde yaklaşmaya, yetişkin bakışı üretmeye teşvik etmektedir.

Terimi medya çalışmalarında ilk defa Ghent Üniversitesi'nden Emiljano Kaziaj (2016) Arnavutluk televizyon haberlerindeki çocuk temsilleriyle ilgili yaptığı çalışmada kullanmıştır. Çalışmasında hem söylem hem de grafik açıdan çocukların 'yetişkin bakışı' bağlamında temsil edilip yorumlandığını ileri sürer. Kavramı Laura Mulvey'in kadınların nesneleştirilmesi açısından ana akım filmler için kullandığı "erkek bakışı" (male gaze) kavramından ödünç aldığını belirtir. Kaziaj, Mulvey'in kullandığı anlamda anlatı ve kamera kullanımına bir de 'haber unsurlarının perspektifi'ni ekler. Haberlerde kullanılan anlatı öğeleri, hikayeleştirmeler ve söylemler, kamera açıları ve vurgulanan perspektifler (bakış açıları) olarak 3 unsur ele alınır. Kamera açıları için çocukların standart bir biçimde üst açıyla çekilip gösterildiğini, bunun da gerçek hayatta yetişkinlerin görüş açılarıyla uyumlu olduğunu belirtir. Sonuç olarak bu üç unsur çocukları kırılgan bir pozisyona itmektedir. Çocuklar ideal kurbanlardır; çoğunlukla trajik ve talihsiz elementler olarak kullanılırlar, çocukların sesleri 
yoktur, kendi adlarına konuşamazlar; söz hakkı verildiğindeyse sıklıkla önemsenmezler (s.429). Haber programlarından birinde bir çocuğa vatanını mı yoksa kendi hayatını mı daha çok sevdiği sorulur. Çocuk vatanını sevdiğini söyler. "Neden?" diye sorulduğundaysa "onu korumak için her şeyimi veririm" diye cevap verir. Burada muhabir iki seçenekli sorularla almak istediği cevabı hazırlamaktadır. Çocuklara söz hakkı verildiğinde dahi onları bir yetişkin fikrinin fonksiyonu haline getirirler (s.437). Çocuklar bekleme/oluşum halindeki vatandaşlardır. Ancak yetişkin gerçekliğine girdiklerinde etrafındaki olayları kendi bakış açılarıyla yorumlayabilecek yasallıklar haline gelmelerine izin verilir.

\section{Yöntem}

Ulusal bir kanalda prime-time dışında yayınlanan Çocuktan Al Haberi adlı yarışma programında 'yetişkin bakışı' çerçevesinde temsil edilen çocukların hangi imajlarla ve nasıl temsil edildiğini merkezine alan bu çalışmada betimsel analiz, söylem analizi ve gösterge-bilimsel çözümleme yöntemleri kullanılacaktır. Seyirciler tarafından beğeniyle izlenilen ve çocukların "sevimlilikleri", "bilmişlikleri" (performanslar) ile ön plana çıktığ programdaki temsillerin nasıl bir çocuk kimliği inşasını desteklediğini anlatabilmek için gerekli soruları sormak ve önceden belirlenen temalar çerçevesinde özetleyip yorumlamak için betimsel analiz yönteminin açıklayıcı ve yorumlayıcı yaklaşımı ile neden-sonuç ilişkileri kuran, kavramsal çerçeveyle sürekli etkileşim içindeki yöntemi merkeze alınmıştır (Yıld1rım, Şimşek, 1999, s.224).

Bununla birlikte programda çocukların ekrana yerleştirildiği görsel sistem, bakışların örgütlenmesi, sunucunun pozisyonu gibi dilsel özelliklerin anlaşılması için göstergebilimin görüntü ve dil arasında kurduğu bağdan faydalanılacaktır. Çocuktan Al Haberi programında işleyen çocukluk temsillerinin neredeyse tüm toplum tarafından kabul edilen ve benimsenen bir çocuk imgesine dayandığı söylenebilir. Böylelikle programdaki çocuklar "doğal" çocuk imgelerini yansıtıyor diye düşünülebilir. Bu sebeple çalışmanın doğası bir tür mitosun analizini gerektirmektedir. Roland Barthes "Çağdaş Söylenler"i ortaya çıkaran duyguyu tam da böylesi bir genelleşmiş yargıyı 'doğal' olarak kabul eden, tarihselliğinden sıyıran 
insanlara duyduğu öfkeyle açıklar. "Yaşadığımız güncel olayların öyküsünde Doğa ile Tarih'in her dakika birbirine karıştırıldığını görmekten rahatsızlık duyuyor, apaçı ortada olanın süslenip sergilenişinde saklı olduğunu sandığım düşünsel çarpıtmayı yakalamak istiyordum"' (2014, s.7). Ancak böylesi bir gösterge, bilimsel bir çalışmada, gelişim psikolojisi yaklaşımlarında temsil edilen gerçek biyolojik çocukla (Doğa), kültürel olarak inşa ettiğimiz temsil olarak çocuk (Tarih) arasındaki farkı ortaya koymamızı sağlayacaktır. Bu anlamda betimleyici yöntemin kavramlarla ilgili bağlantıları kurarak yorumlayıcı özelliği ile göstergebilimin 'işaretleri' çözümleyen yaklaşımı birbiriyle kolaylıkla kaynaşabilir.

Çalışmada, programdaki 'yetişkin bakışı'nı ortaya koymak için tıpkı Bell' in (1995) ortaya koyduğu söylemler gibi, sunucu ve yarışmacıların çocuklara yönelik söylemleri ya da çocuklara yazılan senaryoda gizlenmiş Çocuksuluk (Childism) söylemlerini de ortaya koymak gerekir. Söylem analizi bir retorik analiz formudur, bir söylem analizine başlamak için mantık, inanılırlık, empati gibi retorik mecazlar araştırılır (Stokes, 2013, s.143-144). Fakat bu çalışmada daha çok çocuklar ve yetişkinler arasındaki güç ilişkileri çözümleneceği için 'eleştirel söylem analizi'nin "metin ve konuşmalardaki ırk, cinsiyet ve sınıfla ilgili güç, hakimiyet ve sosyal eşitsizliklere" yönelik yaklaşımı benimsenecektir (Van Dijk, 2007, s.15). Daha çok niceliksel araştırmalar için kullanılan içerik analizi Drisco ve Maschi (2016) tarafından önerilen betimleyici içerik analizi yönteminde, eleştirel teori uygulaması olarak metinler ve sembolik ifadelerdeki anlamı yorumlamaya çalışmaktadır. Söylem ve konuşma analizi yapılırken anlam odak noktasına alınarak güç ve hakimiyet yapıları çözümlenmeye çalışılır. Bu anlamda betimsel içerik analizinin bir tür yöntemsel sentezi ifade ettiği de söylenebilir (s.82).

"Çocuktan Al Haberi" 28 Temmuz 2019' da 124. bölümünü yayınlamıştır. Program gidişatı içerisinde bir takım değişiklikler yapılmış, örneğin ünlüler programları eklenmiş, bazı çocuklar programdan çıkarken, sonradan popülerleşecek yeni isimler programa dahil edilmiştir. Bu sebeple yayın formatının artık bir şablona dönüştüğü ilk 100 bölüm içerisinden amaçlı örneklem yöntemiyle 8 bölüm seçilmiştir. Amaçlı örneklem, olay, inanç ve eylemlere yeni bir perspektif, tanımlama, yeni bir bilinçlilik sağlamak için farklı bilgi ve metinlerden veriyi toplamayı öngörür. Örneklem, bilinmeyen bir perspektif ya da anlamı ortaya çıkarmak ve yeni bir 
bilinçlilik yaratmak için genelleştirme eğilimi riskini de üzerine alır (Drisco, Maschi, 2016, s.98).

\section{Bulgular}

Çocuktan Al Haberi ulusal kanalda, prime-time dışında yayınlanan bir yarışma programıdır. Program çok yakın formatlarda ilk defa 1998 yılında Berna Laçin sunumunda yayınlanmış, bundan sonra 2007 yılında tekrar Berna Laçin sunumuyla yayınlanıp 2 bölüm sonra yayından kaldırılmıştır. 2009 yılında Bergüzar Korel'in sunumunda, 2011'de Açelya Akkoyun sunumunda tekrar yayına girip çıkmıştır. İnceleyeceğimiz program 3 Aralık 2016 tarihi itibariyle yayına başlayıp, izleyiciler tarafından büyük ilgi görmesi dolayısıyla "Çocuktan Al Haberi Ünlüler" gibi bir ek program daha yapan, Evrim Akın sunuculuğunda gerçekleşen "Çocuktan Al Haberi" programıdır (Çocuktan Al Haberi, Wikizero). Program, en basit ifadeyle, üç yarışmacının, çocuklara sorulan sorulara verdikleri cevapları tahmin etmeye çalışmasına dayanır. Bu noktada çocukların huy, karakter, alışkanlık gibi mizacına dair bir takım öngörüler dışında yarışmacıların herhangi bir bilgiye ihtiyaçları yoktur. Çocukların çoğu kez ön görülemez cevaplar vermeleri, kendileri gibi kişiliklerinin de gelişim halinde oluşu sebebiyle daha çok şans faktörü ön plandadır. Programda yaşları 3 ile 5 arasında değişen 9 çocuk vardır. Bu 9 çocuk kendisine daha önceden sorulan sorulara cevaplar verirler, bu cevaplar önceden kaydedilir ya da çocuklar belirli senaryolar çerçevesinde bazı cevaplar verirler. Çocukların çekimleri tek tek yapılmıştır. Fakat içinde dokuz küçük kutucuk olan büyükçe bir televizyon dekoru içinde grafik olarak kutucuklu bir sistem içinde temsil edilirler. Çocukların programa katılımı canlı olarak gerçekleşmese de sunucu ve yarışmacılar çocuklarla doğrudan konuşuyormuş gibi yaparlar. Programda çocuklarla önceden çekim yapıldığı, soruların önceden hazırlanıp sorulduğu gizlenmez. Çocukların görüntülerinde sürekli yapılan sıçramalı kurgu kesmeleri (jump-cut) görüntüler üzerinde oynand1ğını açıkça gösterir.

Yarışma yapısal olarak iki bölüme ayrılmıştır. İlk bölümde yarışmacılar ve çocuklar kendilerini tanıtırlar. Yarışmacılar, isimlerini, işlerini, memleketlerini, hobilerini vb. kişisel özelliklerini anlatırlar. Yarışmacılara sıklıkla çocuklarla iyi geçinip geçinmediği benzeri sorular sorulur. Daha 
sonra çocuklar kendilerini tanıtmaya başlarlar. Çocuklar isimlerini ve yaşlarını söyledikten sonra "doğaçlama" bir biçimde yöneltildiği izlenimi uyandıran bir takım sorularla ilk ilginç ve eğlenceli performanslarını gerçekleştirirler. Burada özellikle çocukların çocukluklarını gösterebileceği ilginç sorular, 'çocuktan al haberi' mantığıyla aileleriyle ilgili özel sorular sorulur ve ilginç yorumlar yapmaları beklenir. Yarışmanın yapısal olarak ikinci bölümü 'yarışma' bölümüdür. Bu bölüm de kendi içerisinde parçalara bölünür. 1. turda çocuklara bir soru sorulmuştur; "'ya o, ya bu' mantığıyla ikili seçenekten birini seçmesi beklenen çocukların hangi seçeneği seçtiği tahmin edilmeye çalışılır. Çoğunluğun seçtiği seçeneği bilenler puan kazanırlar. Sonraysa yarışmacılar hangi çocuğun hangi seçeneği seçtiğini bilmeye çalışırlar. En az puan kazanan yarışma sonunda elenir ve 2 . tur 2 yarışmacıyla devam eder. 2. turda yeniden çocuklara iki seçenekli bir soru sorulur. 1. turdan tek farkı çocukları yarışmacıların kendi seçemez. Bir butona basmaları ve imlecin üzerinde durduğu çocuğun cevabını tahmin etmeleri gerekir. Bu tur sonunda da az puanlı yarışmacı elenir. 3 . turda kalan son yarışmacı 9 çocuk içinden 5 tanesini seçer. Çocuklara bu turda iki seçenekli soruların bir türevi olarak "'bilmiş midir, bilememiş midir?" ya da olumlu olumsuz cevaplara yönlendiren iki seçenekli sorular sorulur. Yarışmacı doğru tahminde bulunduğu çocuklardan puan alır. 500 puanı geçen yarışmacı (hemen hemen tamamı) yurtdışında çift kişilik bir tatil ödülü kazanır. Programın finalinde kazanan yarışmacı finalde tebrik edilir, kısa bir kapanış konuşması sonunda program sonlanır. Programın bu iki yapısal bölümüne zamanla küçük eklemeler yapılmıştır. Sunucunun tanıtıcı konuşmaları ve 'Az Sonra' jenerikleri dışında program zamanla ilerleyip çocukların tiplemeleri belirginleştikçe kısa ve özel performans bölümleri eklenmiştir. Yemekleri çok sevdiği için katılımcı çocuklardan Ebrar, 'Ebrar'dan Al Tarifi' bölümlerinde yemek tarifi verir. Robotları çok seven Efe, 'Efe' yle Pratik Bilim'de ilginç deneyler yapar. Şarkı söylerler, masal anlatırlar, dans ederler, bir tekerlemeyi söylemeye çalışırlar.

Çocuktan Al Haberi ödülün nahifliği ve programın ana konusunun çocukların verdiği eğlenceli cevaplar olması sebebiyle zayıf bir yarışma duygusuna sahiptir. Fiske'ye (1987) göre, yarışma programlarında fırsat eşitliği olan, fakat kabiliyetleri farklı olan yarışanlar bir mücadele içine girer ve giderek eşitsizlikleri ortaya çıkarak bir kazanan ortaya çıkar. Galip gelen kişiye fetişisttik bir gösterişle ödülü verilir. Çocuktan Al Haberi bir bilgi 
yarışması (quiz game) formuna benzemekte fakat yarışmacıların 'bildiği' şeyler, onların bilgi dağarcığının genişliğini ya da entelektüel zeka düzeylerini göstermemektedir. Çocuktan Al Haberi aslında yarışma görünümünde bir eğlence programıdır. Örneğin yarışmalar bir şekilde izleyiciyi de katılıma davet eder. Ekran başındaki insanlar da doğru cevabı bilmeye çalışır ya da yarışmacıların fiziksel performanslarıyla özdeşleşerek kendi yeterliliklerini düşünür ya da hayali bir düzlemde sinar. Çocuktan $\mathrm{Al} \mathrm{Ha-}$ beri bilgi ya da şansın neredeyse önemsiz olduğu, daha çok çocuk performanslarının ön plana çıktığı bir programdır. Rekabete dayalı bir gerilim ve heyecana ortak olmayız, çocukların keyif veren performanslarıyla eğleniriz. Programın bir yarışma olmama hali, biçimin bizzat kendisinin 'yetişkin bakışı'nın üretilmesinde etken olduğunu göstermektedir.

\section{Tartışma}

Çocuktan Al Haberi Türkiye'nin beğenisini kazanmış bir programdır. Birçok izleyici çocukların sempatiklikleri, büyümüş de küçülmüş halleri, zekaları ve taklitlerini izleyerek eğleniyor ve hepsine ayrı ayrı sevgi besliyor. Ancak bu sevginin altında hiçbir zaman fark edemediğimiz bir ayrımcılık ve güç ilişkisi gizlidir. Piaget'nin (2000) dikkat çektiği gibi çocukların işlem-öncesi "büyükmüş gibi" hareketleri çocukların kaygı, korku, endişe, fobi, öfke, saldırganlık gibi eğilimlerini yansıtan sembolik ifadelerdir, çocuğun bunlara karşı kavramsal bir bilinci, bir tür işleme yeteneği yoktur. Performansları bir takım sembolik dışavurumlar ve taklitlerdir, bu sebeple kolaylıkla "büyümüş de küçülmüş" olarak algılanabilirler. Programın anlatı düzleminde çocukların bu gelişim aşamaları bir mizah unsuru olarak kullanılmaktadır. Yetişkincilik çocukların bağımsız varlıklar, gelişen bireyler olarak görülmesini engellemektedir.

Bu bakış tam da modern çocuk imgesinin örtük unsurlarını kapsamaktadır. Aries'in (1962) belirttiği bağımlılık fikrinden beslenen bu çağdaş imge, tıpkı yetişkinlerin aciz ve yetersiz olduğu durumlarda çocuklaştırılmaları gibi, modern anlamda çocuğun, bir tür gizli bağımlılık, güç ve hakimiyet ideolojisini yansıtmaktadır. Tarihsel, coğrafi, ekonomik ve kültürel yapılar tarafından tanımlanan ve böylece yetişkin beklentilerinin bir fonksiyonu olarak oluşturulan (Heywood, 2001) çocukluk, Çocuktan Al 
Haberi eğlence programında kültürel bir temsil haline gelmektedir. Çocuklar kendilerinden beklenen mekan ve desenlere uyarak, aynı zamanda keyif veren eğlence araçlarına dönüştürülmektedir (Holland, 2004).

Modern, kentli, orta sınıf ailelere hitap eden Çocuktan Al Haberi'nin çocuk temsilinde Cumhuriyet'in ve geleneksel aile modellerinin içerdiği "itaatkar ve dürüst" çocuk imgesi yerine keyif verici performanslarıyla ön plana çıkan 'oyuncu' çocuklar temsil edilmektedir. Kentli aile çocuğa "başkalarına gösterilecek, onlarla ya da onları kullanarak eğlenilecek, keyif alınacak, hayata bir değişiklik katacak varlıklar" (Kağıtçıbaşı, 1981) olarak bakmakta ve programda da bu bakış açısı yeniden üretilmektedir. Çocukların, sevimli ve taklitçi olarak konumlandığı program hakim bakış açısını da yeniden-üretmektedir. Çünkü diğer kitle iletişim araçları gibi televizyon da mesajlar yoluyla var olan kültürel yargı ve değerleri yansıtmakta (Oğuz, 2000), bir tür ideolojik işlevi yerine getirmektedir.

Programda kurulan söylem yapısı iki temel unsura dayanmaktadır: Öncelikle sunucu ve yarışmacıların, sonra bizzat çocukların söylemleriyle, sevimli, beceriksiz, sempatik, masum ve 'doğal' olarak sevimli çocuk temsili (1), çocuk ve yetişkinleri birbirinden ayıran olumlu-olumsuz olarak sinıflanıp karşılıklı olarak birbirine nasihatler şeklinde verilen bilmiş çocuk temsili (2). Bunların ötesinde söylemin kuruluşu belirli senaryoları dayandığı için ortaya çıkan bu kimlikler çocuklar adına oluşturulmuş ve bir eğlence unsuru haline getirilmiştir. Görsel yapıda hakimiyet ilişkisi sürdürülmüş, çocuklar kısıtlı çerçevelerde temsil edilmiş, 9 kutucuklu görsel yapı, çocukların yetişkin bakışının zevki için sunulmuş seyirlik performansçılar olarak temsil edilmesini desteklemiştir.

Çocukları benzersiz kendilikler, bağımsız bireyler olarak görmek yerine performanslarıyla keyif verici nesneler, üzerinde hakimiyet kurulacak, denetlenecek gelişmemiş varlıklar olarak görüyoruz. Bu ilişki sadece zorbaca yöntemlerle (dayakçı eğitim gibi) kurulmak zorunda değildir; yetişkin bakışının gizli güçleri bu tür bir 'Yetişkinciliği' yeniden üretebilir. Çocuktan Al Haberi de bu tür bir ilişkiyi bakış yoluyla ve programda sunucu, yarışmacı ve çocukların senaryolarına dayanan söylemlerle sürdürürler.

Çocuk imgeleri ile toplumda yaygın, başat ideolojiler arasında gizli bir ilişki vardır. Çocuklara karşı geliştirilen bakış açıları aynı zamanda yetiş- 
kin toplumun kendisine 'ne' olduğunu söyleme tarzlarını yansıtır. Bu anlamda yetişkin bakışı sadece kitle iletişim araçlarında değil toplumun bizzat kendi içinde oldukça yaygındır. Yetişkin birey, çocuğu çocuklaştırarak kendi kimlik inşa sürecine eklemler. Bu sebeple konusu ve içeriği çocuklar olan bir yarışma programı olarak Çocuktan Al Haberi bir çocuk programı değil yetişkinler için tasarlanmış ve onların bakışına ve zevkine sunulmuş bir eğlence programıdır.

\section{Sonuç}

Sıklıkla çocuklar adına konuşulduğundan, onların seslerinin olmamasından, fikirlerinin sorulmamasından rahatsızlık duyulur, eğitimli aileler bundan şikayet ederler. Bir TV programında çocuklara düşünceleri sorulurken dahi onlara ezberletilmiş cevaplar verdirerek, nasıl oynamaları gerektiklerini dahi söyleyerek bir tür maske yaratılmaktadır. Çocuklar aktif olarak gösterildiğinde dahi medya sistemimizin içinde pasifleştirilmektedirler. Üstelik çocukların nasıl gözükmeleri gerektiğine dair bir yetişkin bakışı (adult gaze), yapay kimliklerle çocukları kategorize etmekte, onları "nasıl görüyorsak öyle" yanılsaması içinde dönüşüme uğratmaktadır. Üstelik onlara yapıştırılan bu roller, programın 9 oyuncusu için ileride çarpık bir karakter gelişimine yol açacağı söylenebilir. Bu anlamda Aile ve Sosyal Politikalar Bakanlığı çocukların psikolojik destek alması için harekete geçmiştir (Özgenç, 2017).

Çocuktan Al Haberi programının bilmiş ve sevimli çocukları onların gerçek özerk varlıklarını değil, yetişkin bakışının onlarda görmeyi arzuladığı desenleri yansıtmaktadırlar. Çocuklar neredeyse patolojik olarak görülebilecek, kafes benzeri bir kutucuklu yapıda, senaryolara dayalı performanslarla bir seyirlik mekanizmanın parçası haline getirilmektedirler. Kentli orta sınıfın çocuğu gösterişçi bir bakışla başkalarına sunulacak ve eğlenceli performanslarıyla öne çıkaran eğilimi bu ve benzeri medya temsillerinde sıklıkla ön plandadır. Bu bakış açısı gizli bir güç ve hakimiyet duygusunu besleyerek yetişkinin sürekli kendi kendini olumlamasına hizmet ederek düalistik bir düşünsel yapısı kurar. Modernitenin bir uzantısı olan bu yapıda çocukluk zayıflıkla, yetişkinlik medeniyetle özdeşleştirilir, böylece yetişkin olmak çocuğun yanında önsel ve özünde bir güç barındırmaya başlar. Medya temsillerinde Yetişkin Bakışı ile örgütlenen 
bu iktidar Yetişkinciliği oluşturan ve besleyen bir yapı oluşturmaktadır. Çocukların gelişimlerinde bir engele dönüşen bu Yetişkinci yaklaşımın yaygın ve örtük/gizli mekanizmaları farklı medyalarda ve sosyal yaşamın değişik alanlarında da ortaya çıkarılmalıdır. 


\section{EXTENDED ABSTRACT}

\section{Representations of Children Produced by the Adult Gaze in the "Çocuktan Al Haberi" Quiz Show and Adultism \\ * \\ Erman Bostan \\ Anadolu University}

Children and the media are often discussed in the context of 'negative effects' and explained in the aspect of their use. This approach is also maintained by governments and non-governmental organizations that are committed to protecting children from media influences and binding over a healthy relationship with messages. The second dimension of the discussions about children and media is child representations. The researchers are often examined the representation of children and their position and gender roles in the family in the context of the tradition of cultural studies and the positive and negative representations of the identity of the child represented in different media tools. Many of these studies are based on the image of a 'natural child', healthy and normal, whose educational, housing and nutritional needs must be met, which can be viewed as a representation of innocence and intactness. This 'natural child' image, which is clearly evident in UNESCO and the UN's declarations on children's rights, is based on a child design that emerged about 200 years ago. Feeding through the values system of the Renaissance and the Enlightenment and adapted to the social structures of the printing press and industrial revolutions, this child design has developed continuously through different processes of change. Nevertheless, the Adultism perspective has implicitly centered on the child design of the last two centuries, in which the child and the adult are separated in a hierarchical power relationship.

Childhood can be considered primarily as a biological phenomenon. But childhood is a social fiction, unlike the infancy stage, which is smaller than adults, who cannot walk, speak, and cannot fulfill its basic needs by itself. In developmental psychology, different psychic and cognitive 
stages of transition from childhood to adulthood can be observed by segmenting the childhood stage into a series of periods. However, this scientific point of view turns into an approach in social discourse that approaches the child as incapable, non-civilized, needy, uncontrolled and control, in-progress people who need to become civilized and mature. In the design of this child, whose anthropological origins are based on the duality of father-gods and sons of religious rituals, the child represents both innocence, purity, curiosity, freshness and tenderness as well as egocentricity, rawness, indecision, credulity, and distance from wisdom.

The adult gaze, like the male gaze (Mulvey, 2004), establishes a distinction between adult and child and a kind of power relationship that is organized through mutual view. The gaze is based on a process of constructing a dual type: by looking at the dominance over the other and the looking subject constructs himself through the view. The adult gaze forces children to settle in the spaces expected from them and to follow the expected patterns. The look is twofold, as in child representations: power and pleasure. Power comes from the superior knowledge of adults about life and the pleasure comes from the beauty of childhood. Such images often appear in media representations serve a kind of ideological system called Adultism. Adultism can be defined as the ability of adults to see children differently as if they were another species, just as in racist, sexist or elitist modes of behavior. Not only parents, but also teachers, religious officials, lawyers and psychotherapists force children to act in accordance with the image of the child in their minds. This is also the way that the adult autosuggests himself. Children are revealed a kind of Childism by submitting to adult behaviors and adapting themselves to their children's images. Adultism is not only reproduced in the field of visual representation through the look, but also constructed through discourses. "Too smart for your age", "don't grow up enough to understand it", "don't be child", "hey, kid" are commonly used. Such calls lead the child or other person to a weaker position than himself.

In the quiz show "Çocuktan Al Haberi" (Similar to this idiom are use in different format in English. Children and fool tell the truth, little pitchers have long ears are some of them. It's meaning in Turkish about get the news from children), Adultism is reproduced through the adult gaze of visual indicators and the discourse of the contestants and the presenter. In 
the light of Semiotics and Critical Discourse Analysis methods which was examined from a descriptive perspective, it was understood that the game show was not based on a competition but a fun and comedy show established on children. "Çocuktan Al Haberi" is based on the fact that contestants estimate their answers to the questions asked to children. In this prediction competition, which takes place away from the dramatic tension of the feeling of competition, the competitors do not have to rely on any information, and the behavior of the children does not conform to the patterns thought about them. Moreover, the grand prize is a double holiday, which can be considered as insignificant. Thus the sense of competition remains in the background. The only element worth seeing in the game is the performance of children. The audience is entertained by the unexpected answers given by the children or other narrative pieces such as fairy tales and songs. Two types of representations emerge in the field of discourse: inability to use objects, harmless mistakes and deficiencies in language competence and weaknesses as 'cute child' images, with representations, cunning, unexpected way of thinking the 'clever child' image. These two representations of children are created by a pattern that adults expect from them and are presented to the audience as 'natural child'. More importantly many of the children's words are based on scripts, therefore, children do not speak mostly, they say their lines. In addition to the improvised answers, these intervening scripts turn children into performers: cute, playful, respectful to their parents, intelligent and message carrier for the adults.

The visual language of the show also reproduces the power relationship of the adult gaze over children. 9 children are projected on 9 split screens. The screens resemble cages in pet shops or showcases of electronic markets. In this sense, 9 children were compressed into a construction that allows adults to provide the pleasurable glance at the child performances they expect from them. It's a kind of spectacle play. Adults are standing, framed by long shots. Children are framed by close-up shots, their mobility is limited. The presenter is the authority figure at the center of the studio, and the children's gaze is directed at the presenter they call "Sister Evrim". Shooting at children's eye level gives a sense of intimacy; shot-reverse shot create the illusion of mutual conversation, and thus the 
ideology of the show Adultism is hidden behind naturalness and intimacy, vitality and now-and-here feelings. As a result, "Çocuktan Al Haberi" is an adult entertainment show. The pleasure stems from children's performances created through the look and discourse.

\section{Kaynakça / References}

Alver, F. (2004). Neil Postman'in çocukluğun yok oluş sürecinde iletişim teknolojisi eleştirisinin eleştirisi. İletişim Araştırmaları, 2(2), 129-141

Ariès, P. (1962). Centuries of childhood. (R. BaldickTransl.), New York: Alfred A. Knopf

Aydın, D. (2009). Tinercilerin” bir korku nesnesi olarak temsili. Toplum ve Kuram, 2 (1), 43-52

Barthes, R. (2014). Çă̆daş söylenler. (T. Yücel Çev.). İstanbul: Metis

Casey, B., Casey, N., Calvert, B., French, L. and Lewis, J. (2008). Television studies: The key concepts. New York and London: Routledge

Culpeper, J. (2005). Impoliteness and entertainment in the television quiz show: The weakest link. Journal of Politeness Research, 1, 35-72

Cunningham, H. (1996). The history of childhood. In (E. M. Lamb, C.P. Hwang, I.E. Siegel, Ed.), Images of Childhood. New Jersey: Lawrence Erlbaum Associates, Publishers

Daşçı, S. (2008). Avrupa resminde çocuk imgesi. İstanbul: Bağlam Yayıncılık

Drisko, J. W. ve Maschi, T. (2016). Content analysis. New York, Oxford: Oxford University Press

Durna, T. ve Kubilay, K. (2010). Basının şiddeti: Siyasal gösterilerde "polise taş atan çocuklar" örneği. Ankara Üniversitesi SBF Dergisi, 65(3), 5185

Ercan, R. (2014). Anne babaların gözünde sahip olduğu çocuk imgeleri. The Journal of Academic Social Science Studies, 30(1), 377-396

Fiske, J. (1987). Television culture. London: Routledge

Flasher, J. (1978). Adultism. Adolescence, 13(51), 517-523.

Foucault, M. (2015). Hapishanenin doğuşu. (M. A. Kılıçbay Çev.). İstanbul: İmge

Freud, S. (2002). Totem ve tabu. (K. S. SelÇev.). İstanbul: Sosyal Yayınlar Freud, S. (2015). Cinsellik üzerine. (E. Kapkın Çev.). İstanbul: Payel Yayınları Gauntlett, D. (2008). Media, gender and identity. London and New York: Routledge 
Güven, S. (2014). Çocukların medyada temsili: İyi, kötü ve mağdur çocuk. Yayınlanmamış doktora tezi. Selçuk Üniversitesi/Sosyal Bilimler Enstitüsü, Konya.

Hall, S. (1997). Representations: Cultural representations and signifying practicies. London: Sage

Heywood, C. (2001). A history of childhood. Malden: Blackwell

Holland P. (2004). Picturing childhood. London, New York: I.B. Tauris

Howe, N.A. ve Yarbrough, W. (2014). Kidding around: The child in film and media. New York, London: Bloomsbury

Kağıtçıbaşı, Ç. (1981). Çocuğun değeri: Türkiye'de değerler ve doğurganlık. İstanbul: Boğaziçi Üniversitesi

Kalan, Ö.K. (2010). Reklamda çocuğun toplumsal cinsiyet teorisi bağlamında konumlandırılışı: 'Kinder' reklam filmleri üzerine bir inceleme. İletişim Fakültesi Dergisi, 38(1), 75-89

Kant, I. (2009). An answer to the question: What is enlightment?. (H.B. Nisbet Transl.). London: Penguin.

Kaşıkçı, D.N., Çağıltay, K., Karakuş, T., Kurşun, E. ve Ogan, C. (2014). Türkiye ve Avrupa'daki çocukların internet alışkanlıkları ve güvenli internet kullanımı. Eğitim ve Bilim, 39(171), 230-243

Kaziaj, E. (2016). “The adult gaze": Exploring the representation of children in television news in Albania. Journal of Children and Media, 10(4), 426-442

Lacan, J. (2013). Psikanalizin dört temel kavramı. (N. Erdem Çev.). İstanbul: Metis

Lemish, D. (2015). Children and media: A global perspective. West Sussex: Wiley Blackwell

Livigston, S. (2016). Reframing media effects in terms of children's rights in the digital age. Journal of Children and Media, 10(1), 4-12.

McGowan, T. (2012). Gerçek bakış. (Z. Özen Barkot Çev.). İstanbul: Say Yayınları

Mulvey, L. (2004). Visual pleasure and narrative cinema. In (L. Braudy, M. Cohen, Ed.) Film Theory \& Criticism (7th ed.). New York, Oxford: Oxford University Press.

Oğuz, G. Y. (2000). Televizyon: Kaçınılmaz öğreticimiz: Televizyonun toplumsal iletişimdeki yeri. Kurgu, 17, 22-34

Onur, B. (2005). Türkiye'de çocukluğun tarihi: Çocukluğun sosyo-kültürel tarihine giriş. Ankara: İmge Kitabevi 
Özmen, Ş.Y. (2012). Çocuğun adı yok: Televizyon haberlerinde çocuğun sunumu ve çocuk hakları bağlamında değerlendirilmesi. İletişim $\mathrm{Ku}$ ram ve Araştırma Dergisi, 34. 66-82

Öztan, G.G. (2011). Türkiye'de çocukluğun politik inşası. İstanbul: İstanbul Bilgi Üniversitesi Yayınları

Pembecioğlu, N. (2006). Türk ve dünya sinemasında çocuk imgesi. Ankara: Ebabil Yayınları

Piaget, J. (2000). The psychology of the child. New York: Basic Books.

Postman, N. (1995). Çocukluğun yokoluşu. (K. İnal Çev.). Ankara: İmge Kitabevi

Rousseau, J.J. (2016). Emile ya da eğitim üzerine. (Y. Avunç Çev.). İstanbul: İş Bankası Kültür Yayınları

Sander, Å. (1996). Images of child and childhood in religion. In (M. E. Lamb, , C.P. Hwang, I.E. Siegel, Ed.). Images of Childhood. New Jersey: Lawrence Erlbaum Associates, Publishers

Slade, A. ve Wolf, D. P. (1999). Children at play: Clinical and developmental approaches meaning and representation. New York ve Oxford: Oxford University Press

Şirin, M.R. (2011). Çocuk hakları ve medya el kitabı. İstanbul: Çocuk Vakfı Yayınları

Tutar, C. (2014). Yazılı basında çocuk haklarının temsili: Hürriyet, Cumhuriyet, Sabah ve Zaman gazeteleri üzerinde yapılan bir araştırma. Journal of Yasar University, 9(34), 5760-5786

Van Dijk, T. (2007). Discourse studies. London: Sage

Yıldırım, A. ve Şimşek, H. (1999). Sosyal bilimlerde nitel araştırma yöntemleri. Ankara: Seçkin Yayınevi

Özgenç, M. (2017, 7 Eylül). Efecanları koruma kurulu: Sömürülmelerine izin verilmeyecek, Hürriyet.

Bell, J. (1995). Understanding adultism. http://www.nuatc.org/articles/pdf/understanding adultism.pdf

http://www.tuik.gov.tr/PreHaberBultenleri.do?id=27819

http://www.unesco.org/education/pdf/CHILD_E.PDF

http://cocukhaklari.barobirlik.org.tr/dokuman/mevzuat uamevzuat/birlesmismilletler.pdf

http://www.wikizero.net/index.php?q=aHR0cHM6Ly90ci53aWtpcGVkaWEub3JnL3dpa2kvw4dvY3VrdGFuX0FsX0hhYmVyaQ 


\section{Kaynakça Bilgisi / Citation Information}

Bostan, E. (2019). "Çocuktan al haberi" yarışma programında yetişkin bakışının ürettiği çocuk temsilleri ve yetişkincilik. OPUS-Uluslararası Toplum Araştırmaları Dergisi, 14(20), 784-816. DOI: 10.26466/opus.601065 